NBER WORKING PAPER SERIES

\title{
THE DETERMINANTS AND LONG-TERM PROJECTIONS OF SAVING RATES IN DEVELOPING ASIA
}

\author{
Charles Yuji Horioka \\ Akiko Terada-Hagiwara \\ Working Paper 17581 \\ http://www.nber.org/papers/w17581
NATIONAL BUREAU OF ECONOMIC RESEARCH
1050 Massachusetts Avenue
Cambridge, MA 02138
November 2011

We thank Jong-Wha Lee, Kwanho Shin, Dennis Tao Yang, and the other participants of workshops in Seoul and Hong Kong, David Cook, Desiree Desierto, Julen Esteban-Pretel, Alessandra Guariglia, Minchung Hsu, Alistair Munro, Wade Pfau, Pengfei Wang, and other seminar participants at the Asian Development Bank, Chinese University of Hong Kong, Durham University, Hong Kong University of Science and Technology, and the National Graduate Institute for Policy Studies, and two anonymous referees for their helpful comments, and Aleli Rosario and Shiela Camingue for their superb assistance. This paper was prepared under the Asian Development Bank's TA7470-REG: Long-term Projections of Asian GDP and Trade. The views expressed in this paper are those of the authors and do not necessarily reflect the views or policies of the Asian Development Bank, lits Board of Governors or the governments they represent, or the views of the National Bureau of Economic Research.

NBER working papers are circulated for discussion and comment purposes. They have not been peerreviewed or been subject to the review by the NBER Board of Directors that accompanies official NBER publications.

(C) 2011 by Charles Yuji Horioka and Akiko Terada-Hagiwara. All rights reserved. Short sections of text, not to exceed two paragraphs, may be quoted without explicit permission provided that full credit, including $(\mathrm{C}$ notice, is given to the source. 
The Determinants and Long-term Projections of Saving Rates in Developing Asia

Charles Yuji Horioka and Akiko Terada-Hagiwara

NBER Working Paper No. 17581

November 2011, Revised November 2011

JEL No. D91,E21,G10,J11

\begin{abstract}
$\underline{\text { ABSTRACT }}$
In this paper, we present data on trends over time in domestic saving rates in twelve economies in developing Asia during the 1966-2007 period and analyze the determinants of these trends. We find that domestic saving rates in developing Asia have, in general, been high and rising but that there have been substantial differences from economy to economy and that the main determinants of these trends appear to have been the age structure of the population (especially the aged dependency ratio), income levels, and the level of financial sector development. We then project future trends in domestic saving rates in developing Asia for the 2011-2030 period based on our estimation results and find that the domestic saving rate in developing Asia as a whole will remain roughly constant during the next two decades despite rapid population aging in some economies in developing Asia because population aging will occur much later in other economies and because the negative impact of population aging on the domestic saving rate will be largely offset by the positive impact of higher income levels.
\end{abstract}

\author{
Charles Yuji Horioka \\ Institute of Social and Economic Research \\ Osaka University \\ 6-1 Mihogaoka, Ibaraki-shi \\ Osaka-fu 567-0047 \\ JAPAN \\ and NBER \\ horioka@iser.osaka-u.ac.jp \\ Akiko Terada-Hagiwara \\ Asian Development Bank \\ Manila, Philippines \\ ahagiwara@adb.org
}




\section{Introduction}

Developing Asia has been characterized by high domestic and national saving rates almost across the board in recent years, and these high saving rates have made possible high levels of domestic investment but have also led to large capital outflows (current account surpluses) (see, for example, the data presented in Park and Shin (2009)). To put it another way, the developing economies of Asia have oversaved and underinvested, leading to large current account imbalances (surpluses), as asserted by Bernanke (2005) and others.

The purpose of this paper is to present data on trends over time in domestic saving rates in twelve economies in developing Asia during the 1966-2007 period, to analyze the determinants of those trends, and to project trends in domestic saving rates in these same economies during the next twenty years (2011-2030 period) based on the estimation results. The twelve economies included in our analysis are the People's Republic of China (PRC); Hong Kong, China; India; Indonesia; Republic of Korea (hereafter Korea); Malaysia; Pakistan; Philippines; Singapore; Taipei,China; Thailand, and Viet Nam, which comprise 95 percent of the GDP of developing Asia. This paper contributes to the literature in several respects. First, it presents and compares data on both nominal and real domestic saving rates, even though few past studies have looked at real rates despite their importance. Second, it examines the nonlinear impact of financial sector development on the saving rate, which is particularly relevant for our sample of countries. Finally, it generates long-term projections based on the estimation results.

This paper is organized as follows: In section 2, we present our estimation model of the determinants of domestic saving rates; in section 3 , we discuss past trends in domestic saving rates and in the determinants thereof in developing Asia; in section 4, we present our empirical results 
concerning the determinants of domestic saving rates in developing Asia; in section 5, we discuss our future projections of domestic saving rates in developing Asia; and section 6 concludes.

To summarize the main findings of this paper, we find that domestic saving rates in developing Asia have, in general, been high and rising but that there have been substantial differences from economy to economy, that the main determinants of the domestic saving rate in developing Asia during the 1960-2007 period appear to have been the age structure of the population (especially the aged dependency ratio), income levels, and the level of financial sector development, and moreover, that the direction of impact of each factor has been more or less as expected. We also find that the domestic saving rate in developing Asia as a whole will remain roughly constant during the next two decades because the negative impact of population aging thereon will be roughly offset by the positive impact of higher income levels thereon but that there will be substantial variation from economy to economy, with the rapidly aging economies showing a sharp downturn in their domestic saving rates by 2030 because the negative impact of population aging thereon will dominate the positive impact of higher income levels thereon and the less rapidly aging economies showing rising domestic saving rates, at least until 2020, because the positive impact of higher income levels thereon will dominate the negative impact of population aging thereon.

\section{Estimation Model of the Determinants of Domestic Saving Rates}

In this section, we discuss the estimation model we will use in our econometric analysis of the determinants of domestic saving rates in developing Asia. There have been many previous empirical analyses of the determinants of saving rates using cross-section or panel cross-country data or time series data for individual countries, among them Modigliani (1970), Feldstein (1977, 1980), Modigliani and Sterling (1983), Horioka (1989), Edwards (1996), Dayal-Ghulati and 
Thimann (1997), Bailliu and Reisen (1998), Higgins (1998), Loayza, et al. (2000), Chinn and Prasad (2003), Luhrman (2003), International Monetary Fund (2005), Bosworth and Chodorow-Reich (2007), Kim and Lee (2008), Park and Shin (2009), Horioka and Yin (2010), and Hung and Qian (2010), and a smaller number of studies that conduct similar analyses of the determinants of current account balances, among them Chinn and Ito (2007, 2008) and Ito and Chinn (2009). The present study is based most closely on Higgins (1998), Bosworth and Chodorow-Reich (2007), and Park and Shin (2009).

These studies suggest an important role for demographic variables based on the life cycle model. Looking first at the impact of the age structure of the population, since the aged typically finance their living expenses by drawing down their previously accumulated savings, the aged dependency ratio (the ratio of the aged population to the working-age population) should have a negative impact on the saving rate, and similarly, since children typically consume without earning income, the youth dependency ratio (the ratio of children to the working-age population) should also have a negative impact on the saving rate. Moreover, a higher youth dependency ratio means more children to provide care and financial assistance during old age and less need to save on one's own for old age, and hence the youth dependency ratio could have a negative impact on the saving rate for this reason as well. Park and Shin (2009) and most other studies find that the aged dependency ratio and the youth dependency ratio both decrease the saving rate, as expected.

A high growth rate of real GDP is another important factor, creating a virtuous cycle in which rapid income growth makes it easy to save, and high saving feeds back through capital accumulation to promote further growth. Bosworth and Chodorow-Reich (2007) as well as Park and Shin (2009) find that both contemporaneous and lagged real per capita GDP growth rates increase the saving rate. Moreover, Park and Shin (2009) also find that the level of per capita income has a significant 
nonlinear or more precisely convex relationship with the saving rate in Asia, but Bosworth and Chodorow-Reich (2007) do not find a significant effect.

Aside from demographic and GDP-related variables, financial sector development is also considered to be a crucial determinant of saving rates, but the direction of its impact is ambiguous theoretically as well as empirically. Wang, Xu, and Xu's (2011) theoretical analysis of the impact of financial sector development on the saving rate finds that, if both households and firms are subject to financial friction and if the financial sector development occurs first in the corporate sector and then spreads to the household sector (a likely scenario), then financial sector development will have a hump-shaped impact on the saving rate, initially increasing the saving rate by increasing firms' ability to borrow and invest but then reducing the saving rate by weakening the precautionary saving incentives of households. Turning to empirical studies, Loayza, et al. (2000) as well as Horioka and Yin (2010) find that financial sector development has a negative impact on the saving rate, Park and Shin (2009) find that its impact is insignificant, and Wang, $\mathrm{Xu}$, and $\mathrm{Xu}$ (2011) find a hump-shaped relationship. By contrast, anecdotal evidence suggests that relaxing financial constraints by increasing the availability of saving instruments and accessibility to banks may promote higher saving, as argued by Chinn and Prasad (2003) and Jha, et al. (2009). Thus, both the theoretical and empirical literature suggests the possibility of a nonlinear relationship between financial sector development and the saving rate, and this paper investigates this possibility.

Finally, the real interest rate should, in theory, have an impact on the saving rate although the direction of its impact is theoretically ambiguous.

Thus, the reduced form estimating equation we will estimate is as follows: 
$S R_{i, t}=\beta_{0, i}+\beta_{1} * A G E_{i, t}+\beta_{2} * D E P_{i, t}+\beta_{3} * L N G D P_{i, t}+\beta_{4} * L N G D P S Q_{i, t}+\beta_{5} * \operatorname{CREDIT}_{i, t}+$ $\beta_{6} *$ CREDITSQ $Q_{i, t}+\beta_{7} * X_{i, t}+u_{i, t}$

where $\mathrm{i}=1, \ldots 12(1=$ PRC, $2=$ Hong Kong, China, $3=$ Indonesia, $4=$ India, $5=$ Korea, $6=$ Malaysia, $7=$ Pakistan, $8=$ Philippines, $9=$ Singapore, $10=$ Thailand, $11=$ Taipei,China, and $12=$ Viet Nam $)$; and $\mathrm{t}=1, \ldots 8(1=1966-70,2=1971-75,3=1976-80,4=1981-85,5=1986-1990,6=$ 1991-1995, $7=1996-2000$, and $8=2001-2007)$.

$S R_{i, t}$ represents the real domestic saving rate in country $\mathrm{i}$ at time $\mathrm{t} ; A G E_{i, t}$ is the aged dependency ratio (the ratio of the population aged 65 or older to the population aged $15-64) ; D E P_{i, t}$ is a youth dependency ratio (the ratio of the population aged 14 or younger to the population aged 15-64); $L N G D P_{i, t}$ is the log of per capita real GDP; $L N G D P S Q_{i, t}$ is the square of $L N G D P_{i, t}$, $\operatorname{CREDIT}_{i, t}$ is the ratio of private credit from deposit money banks and other financial institutions to GDP; CREDITSQ ${ }_{i, t}$ is the square of $C R E D I T_{i, t}$, and $X_{i, t}$ is a vector of the other explanatory variables included in the estimation model. $\quad \beta_{0, i}$ is a constant plus country fixed effects when a fixed effects model is estimated. In addition, in some variants, we include $C H G D P_{i, t}$, the growth rate of real per capita GDP and/or $R I N T_{i, t}$, the real interest rate.

In addition, we also try using one-period lags of variables relating to $L N G D P_{i, t}, C R E D I T_{i, t}$, and $C H G D P_{i, t}$ in lieu of contemporaneous values because these variables are endogenous and thus using lagged values thereof would alleviate simultaneity bias. 


\section{Past Trends in Domestic Saving Rates in Developing Asia}

In this section, we discuss past trends in the domestic saving rate and in the determinants thereof in the twelve developing Asian economies in our sample. First, in Table 1 and Figure 1, we present data on past trends in both the nominal as well as real domestic saving rates for each of the twelve developing Asian economies in our sample as well as for these twelve countries as a whole (weighted by real GDP) for each five-year subperiod during the 1966-2001 and for the most recent period, which includes the years from 2001 to 2007.

Nominal domestic saving rates are computed as the ratio of gross domestic saving in current local currency units to gross domestic product in current local currency units and are taken from the World Development Indicators of the World Bank, while real domestic saving rates are computed by subtracting the consumption and government shares of real GDP from 1 and are taken from the Penn World Table, version 6.3 (Heston, et al. (2009)). The nominal and real measures can show divergent trends if trends in GDP and capital goods deflators differ significantly.

As can be seen from this table and figure, there is enormous variation among the twelve economies in the sample in their domestic saving rates, with the nominal domestic saving rate ranging from 39.8 percent in Singapore (and also above 30 percent in the PRC, Malaysia, and Hong Kong, China) to 11.2 percent in Pakistan (and also below 20 percent in Viet Nam and the Philippines) during the 1966-2007 period as a whole. In fact, Viet Nam showed negative real domestic saving rates until she transitioned to a market economy in the 1990s. Korea, Taipei,China, Thailand, Indonesia, and India showed intermediate nominal domestic saving rates during this period. Nonetheless, domestic saving rates were relatively high in developing Asia as a whole relative to the rest of the world throughout the 1966-2007 period. 
Table 1: Trends over Time in Gross Domestic Saving Rates in Developing Asia

\begin{tabular}{|l|r|r|r|r|r|r|r|r|r|r|r|}
\hline Nominal measure & & & & & & & & & & \\
\hline & $\mathbf{1 9 6 6 - 7 0}$ & $\mathbf{1 9 7 1 - 7 5}$ & $\mathbf{1 9 7 6 - 8 0}$ & $\mathbf{1 9 8 1 - 8 5}$ & $\mathbf{1 9 8 6 - 9 0}$ & $\mathbf{1 9 9 1 - 9 5}$ & $\mathbf{1 9 9 6 - 2 0 0 0}$ & $\mathbf{2 0 0 1 - 0 7}$ & Average \\
\hline PRC & 28.9 & 29.1 & 33.0 & 34.8 & 37.0 & 41.9 & 40.7 & 46.2 & 37.8 \\
\hline Hong Kong, China & 28.2 & 29.4 & 33.5 & 31.6 & 36.0 & 32.6 & 30.4 & 31.5 & 31.6 \\
\hline Indonesia & 14.3 & 23.9 & 30.8 & 30.1 & 31.9 & 32.4 & 28.1 & 29.9 & 27.8 \\
\hline India & 15.5 & 16.7 & 18.7 & 19.4 & 21.9 & 23.0 & 22.4 & 29.0 & 22.2 \\
\hline Korea, Rep. of & 15.2 & 19.0 & 27.0 & 27.8 & 36.5 & 36.4 & 35.6 & 31.8 & 28.8 \\
\hline Malaysia & 24.3 & 24.2 & 31.1 & 28.1 & 33.3 & 37.8 & 45.8 & 42.6 & 33.4 \\
\hline Pakistan & 8.9 & 8.0 & 7.9 & 7.2 & 10.3 & 16.4 & 14.9 & 16.1 & 11.2 \\
\hline Philippines & 21.9 & 23.6 & 26.2 & 21.0 & 19.0 & 16.3 & 17.1 & 13.8 & 19.1 \\
\hline Singapore & 18.4 & 26.3 & 34.9 & 43.8 & 41.0 & 47.3 & 49.9 & 46.3 & 39.8 \\
\hline Thailand & 21.2 & 22.8 & 22.1 & 24.3 & 30.8 & 35.8 & 34.3 & 32.2 & 27.9 \\
\hline Taipei,China & 25.3 & 30.4 & 33.0 & 31.6 & 33.4 & 27.2 & 26.0 & 26.0 & 28.7 \\
\hline Viet Nam & & & & & 3.9 & 14.6 & 22.2 & 29.0 & 17.4 \\
\hline Average 1/ & 19.8 & 22.0 & 25.7 & 26.6 & 30.0 & 33.2 & 32.9 & 37.5 & \\
\hline
\end{tabular}

Note: Computed as Gross domestic savings (current LCU) / GDP (current LCU)

1/ weighted by average real GDP of each period

Data source: World Bank, World Development Indicators

\begin{tabular}{|l|r|r|r|r|r|r|r|r|r|r|r|}
\hline Real measure & & & & & & & & & \\
\hline & $\mathbf{1 9 6 6 - 7 0}$ & $\mathbf{1 9 7 1 - 7 5}$ & $\mathbf{1 9 7 6 - 8 0}$ & $\mathbf{1 9 8 1 - 8 5}$ & $\mathbf{1 9 8 6 - 9 0}$ & $\mathbf{1 9 9 1 - 9 5}$ & $\mathbf{1 9 9 6 - 2 0 0 0}$ & $\mathbf{2 0 0 1 - 0 7}$ & Average \\
\hline PRC & 27.3 & 28.3 & 30.1 & 28.1 & 27.0 & 27.7 & 29.4 & 35.6 & 29.2 \\
\hline Hong Kong, China & 35.0 & 34.6 & 35.7 & 33.0 & 33.1 & 28.2 & 27.9 & 33.7 & 32.6 \\
\hline Indonesia & 35.7 & 39.3 & 35.2 & 20.7 & 26.0 & 25.8 & 21.0 & 19.4 & 27.9 \\
\hline India & 12.2 & 13.1 & 14.5 & 12.0 & 12.1 & 12.4 & 10.9 & 16.4 & 13.0 \\
\hline Korea, Rep. of & 18.8 & 21.9 & 31.8 & 33.4 & 39.3 & 42.2 & 42.4 & 43.7 & 34.2 \\
\hline Malaysia & 28.5 & 31.0 & 31.5 & 29.7 & 37.5 & 39.0 & 46.0 & 42.5 & 35.7 \\
\hline Pakistan & 3.8 & 3.4 & -3.8 & -0.8 & 4.8 & 5.9 & 5.2 & 7.7 & 3.3 \\
\hline Philippines & 10.2 & 13.2 & 18.1 & 18.9 & 14.2 & 10.6 & 9.7 & 10.8 & 13.2 \\
\hline Singapore & 35.8 & 40.4 & 45.4 & 53.7 & 51.3 & 56.2 & 60.2 & 56.4 & 49.9 \\
\hline Thailand & 17.9 & 21.0 & 21.7 & 24.8 & 30.4 & 35.2 & 32.8 & 31.7 & 26.9 \\
\hline Taipei,China & 13.4 & 18.4 & 23.1 & 25.1 & 25.5 & 21.7 & 22.6 & 26.4 & 22.0 \\
\hline Viet Nam & -2.4 & -2.4 & -2.4 & -2.4 & -1.7 & 6.9 & 12.6 & 16.8 & 3.1 \\
\hline Average 1/ & 18.8 & 21.0 & 23.0 & 21.2 & 22.8 & 24.3 & 24.8 & 29.4 & \\
\hline
\end{tabular}

Note: Computed as 100 - kc - kg, where "kc" is the consumption share of real GDP per capita and "kg" is the government share of real GDP per capita.

1/ weighted by average real GDP of each period

Data source: Penn World Tables (PWT), version 6.3 
Figure 1: Trends over Time in Gross Domestic Saving Rates in Developing Asia

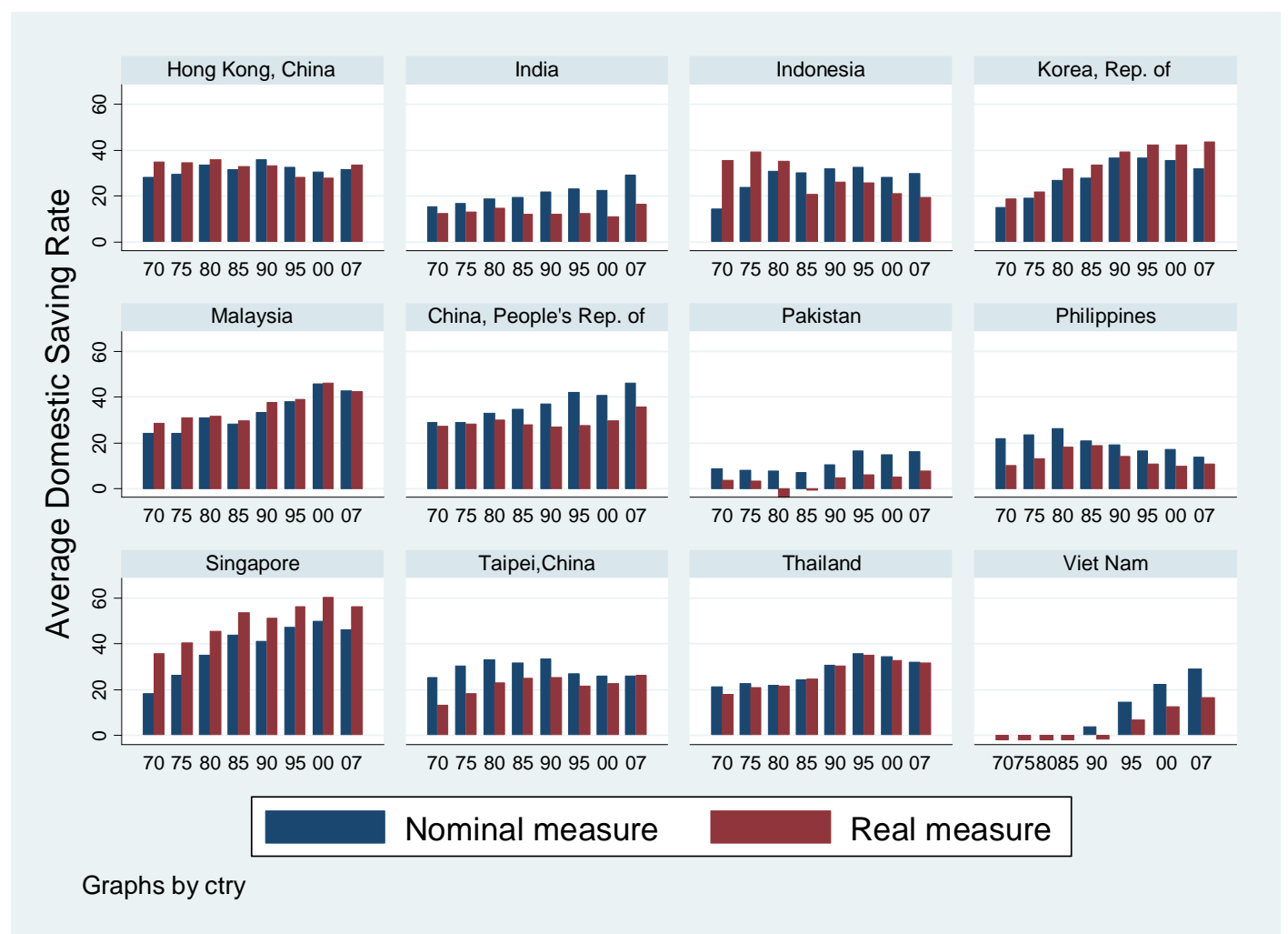

Data sources: See Table 1.

The real domestic saving rate ranged from 49.9 percent in Singapore (and also above 30 percent in Malaysia, Korea, and Hong Kong, China) to 3.1 percent in Viet Nam (and also below 20 percent in Pakistan, India, and the Philippines) during the 1966-2007 period as a whole. The PRC, Indonesia, Thailand, and Taipei,China showed intermediate real domestic saving rates during this period. Thus, the ranking ordering of the twelve countries is roughly the same regardless of whether we look at nominal or real domestic saving rates, with the biggest difference being that PRC falls from second to fifth when real domestic saving rates are used.

Turning to trends over time, both the nominal and real domestic saving rates showed upward trends throughout the 1966-2007 period for the twelve developing Asian economies as a whole, 
increasing from 19.8 (18.8) percent in 1966-70 to 37.5 (29.4) percent in 2001-07 in the case of the nominal (real) domestic saving rate. Overall, the real saving rate tends to be higher than the nominal measure in higher per capita income economies such as Singapore and Korea, and the opposite holds in lower per capita income economies such as Pakistan, Viet Nam, India, and PRC. This is consistent with the notion that capital goods prices will tend to fall or grow more slowly than the GDP deflator as technological progress occurs and the economy grows.

Moreover, the nominal and real domestic saving rates of most individual economies also showed upward trends during most or all of the 1966-2007 period, with the primary exceptions being that the nominal and real domestic saving rates of the Philippines, the nominal domestic saving rates of Hong Kong, China; Indonesia; the Republic of Korea; and Taipei,China, and the real domestic saving rate of Thailand have started declining in recent years, that the real domestic saving rate of Indonesia has been declining throughout the 1966-2007 period, and that the real domestic saving rates of Hong Kong, China, and Pakistan declined in the early years of the 1966-2007 period before turning upward.

Given that the rank ordering of countries and trends over time are broadly similar regardless of whether we use nominal or real domestic saving rates, given that using a real measure is preferable from a theoretical point of view, and given that a number of authors (such as Aghion, Comin, Howitt, and Tecu (2009) and Shioji and Vu (2011)) have used a real measure of saving, we decided to use the real domestic saving rate as our dependent variable throughout our regression analysis. Note, however, that we also tried using the nominal domestic saving rate and that the results were qualitatively very similar (with the main difference being that the coefficient of the AGE variable (to be defined later) is higher in absolute magnitude when the nominal domestic saving rate is used than when the real domestic saving rate is used. 
Various factors affected the trends in domestic saving rates described above. First of all, many of the economies in our sample experienced rapid demographic transition. Life expectancy rose sharply from an average of about 53 in the early 1960s to 73 in the late 2000 s in the sample as a whole. Consequently, the aged dependency rate also increased (from 6.5 to 10.2 percent on average) during the same period. Population aging has been particularly significant in Hong Kong, China; Korea; Singapore; and Taipei,China. Meanwhile, the aged dependency rate has been declining somewhat in Pakistan and Viet Nam. The youth dependency rate shows a uniform picture, declining in all of the economies in our sample, though to a lesser extent in Pakistan.

Financial sector development played an especially significant role in developing Asia. James, et al. (1989) discuss the role played by financial incentives such as raising interest rates on time and saving deposits in increasing the domestic saving rate when the financial system was still shallow in the 1970s (in Korea and Singapore, for example). Financial deepening accelerated in many Asian economies after the mid-1980s, driven by financial liberalization, which relaxed financial constraints and eased access to credit. However, these earlier forms of financial deepening tend to be more relevant for the corporate sector, as often discussed in the context of the financial development and growth nexus (see King and Levine, 1993, for example), and thus they presumably had a positive impact on the saving rate as firms' investments become more profitable and the increasing demand for credit pushed up interest rates. By contrast, improved access to credit by households and the resultant decline in precautionary saving tend to occur at a later stage of development, and thus the negative impact of financial sector development on saving rates will presumably tend to come later. The developing Asian economies in our sample recorded deepening of their credit markets to more than $100 \%$ of GDP by the 2000s except in India, Indonesia, Pakistan, the Philippines, and Viet Nam, and thus further financial deepening can be 
expected to contribute toward reducing their saving rates, unlike in the case of earlier financial incentives and/or the relaxation of financial constraints.

Moreover, these demographic and financial developments were accompanied by the continuing but uneven increase in per capita GDP and its growth rate.

\section{Estimation Results concerning the Determinants of Domestic Saving Rates in Developing Asia}

In this section, we present our estimation results concerning the determinants of domestic saving rates in the twelve developing Asian economies in our sample during the 1966-2007 period.

We estimated both a country fixed effects model and a random effects model with robust standard errors, and we use non-overlapping five-year averages except for the most recent period which includes the years from 2001 to 2007 in order to eliminate the impact of cyclical fluctuations and to focus on long-term rather than short-term variations. Thus, we have maximum of 8 observations per country and a maximum of 78 total observations.

Details concerning the variables used in our analysis (including data sources) can be found in Appendix Table 1, and descriptive statistics can be found in Appendix Table 2.

Our estimation results are shown in Table 2. Models 1-3 are country fixed effects models with no lags, models 4-6 are random effects models with no lags, models 7-9 are country fixed effects models with lags for $L N G D P_{i, t}, L N G D P S Q_{i, t}, C R E D I T_{i, t}, C R E D I T S Q_{i, t}$, and $C H G D P_{i, t}$, and models 10-12 are random effects models with lags for these same variables. 
While the results of standard specification tests such as the Hausman test and the Breusch and Pagan Lagrangian multiplier test suggest the use of random effects models, we show the results for both fixed effects and random effects models. This is because a test of the joint significance of the country fixed effects rejected the null hypothesis that the coefficients of all of the country fixed effects are zero, because omitting country fixed effects seems to increase the residuals for some economies such as the PRC, as also argued by others including Hung and Qian (2010), and because we are interested in knowing whether there are significant country fixed effects when explaining domestic saving rates.

As the results in Table 2 show, our results are intuitive and broadly consistent with those of previous studies. Looking first at the results for the models without lags (models 1-6), the coefficient of AGE (the aged dependency ratio) is negative and significant, as expected, in every case, ranging from -0.83 to -0.98 in the country fixed effects model and from -1.58 to -1.69 in the random effects model. Thus, the absolute magnitude of the coefficient of AGE is much larger in the random effects model than it is in the country fixed effects model and is, in fact, much larger in absolute magnitude than theoretical expectation (the life cycle model predicts that it should equal the negative of the ratio of working years to lifespan and thus should be well below one in absolute value). This is presumably due to omitted variable bias arising from the omission of country fixed effects and other relevant variables. The coefficient of DEP (the youth dependency ratio) is negative, as expected, in almost every case but is totally insignificant in all cases.

Turning to the GDP-related variables, the coefficient of LNGDP (the log of real per capita GDP) is negative and significant, as expected, in all cases, with its square term being positive and significant in all cases, suggesting a nonlinear (convex) relationship with the domestic saving rate, as was also found by Park and Shin (2009). In other words, income levels initially have a negative 
Table 2: The Determinants of the Real Domestic Saving Rate in Developing Asia

\begin{tabular}{|c|c|c|c|c|c|c|c|c|c|c|}
\hline Model & AGE & DEP & LNGDP & LNGDPSQ & CREDIT & CREDITSQ & CHGDP & RINT & R-squared & \# obs. \\
\hline \multicolumn{11}{|c|}{ Country fixed effects model with no lags } \\
\hline \multirow[t]{3}{*}{1} & $-0.95 * *$ & -0.03 & $-43.13 * * *$ & $2.92 * * *$ & $14.48 * *$ & $-6.46 * * *$ & & & 0.76 & 78 \\
\hline & 0.35 & 0.13 & 4.94 & 0.32 & 4.92 & 1.62 & & & 0.61 & \\
\hline & -2.71 & -0.23 & -8.73 & 9.24 & 2.94 & -3.99 & & & 0.70 & \\
\hline \multirow[t]{3}{*}{2} & $-0.98 * *$ & -0.03 & $-44.21 * * *$ & $2.99 * * *$ & $14.58 * *$ & $-6.41 * * *$ & 0.08 & & 0.76 & 78 \\
\hline & 0.38 & 0.13 & 6.19 & 0.39 & 5.01 & 1.70 & 0.14 & & 0.62 & \\
\hline & -2.58 & -0.22 & -7.15 & 7.75 & 2.91 & -3.78 & 0.59 & & 0.71 & \\
\hline \multirow[t]{3}{*}{3} & $-0.83 * *$ & 0.05 & $-35.63 * *$ & $2.53 * * *$ & $14.88 * * *$ & $-6.25 * * *$ & 0.16 & 0.03 & 0.69 & 70 \\
\hline & 0.36 & 0.18 & 13.38 & 0.74 & 4.80 & 1.56 & 0.14 & 0.16 & 0.65 & \\
\hline & -2.28 & 0.27 & -2.66 & 3.40 & 3.10 & -4.00 & 1.15 & 0.19 & 0.72 & \\
\hline \multicolumn{11}{|c|}{ Random effects model with no lags } \\
\hline \multirow[t]{3}{*}{4} & $-1.58 * * *$ & -0.08 & $-46.79 * * *$ & $3.15 * * *$ & $15.35 * * *$ & $-6.71 * * *$ & & & 0.75 & 78 \\
\hline & 0.52 & 0.10 & 8.16 & 0.50 & 5.87 & 1.82 & & & 0.68 & \\
\hline & -3.03 & -0.72 & -5.73 & 6.29 & 2.61 & -3.69 & & & 0.74 & \\
\hline \multirow[t]{3}{*}{5} & $-1.63 * * *$ & -0.07 & $-49.45 * * *$ & $3.31 * * *$ & $15.08 * *$ & $-6.39 * * *$ & $0.24 *$ & & 0.75 & 78 \\
\hline & 0.54 & 0.10 & 8.97 & 0.55 & 5.92 & 1.83 & 0.13 & & 0.70 & \\
\hline & -3.02 & -0.69 & -5.51 & 5.99 & 2.55 & -3.49 & 1.75 & & 0.75 & \\
\hline \multirow[t]{3}{*}{6} & $-1.69 * *$ & -0.62 & $-40.65 * *$ & $2.85 * * *$ & $14.63 * *$ & $-6.15 * * *$ & $0.31 * *$ & -0.04 & 0.66 & 70 \\
\hline & 0.66 & 0.15 & 16.77 & 1.01 & 6.23 & 1.84 & 0.15 & 0.19 & 0.75 & \\
\hline & -2.55 & -0.41 & -2.42 & 2.81 & 2.35 & -3.35 & 2.09 & -0.21 & 0.78 & \\
\hline
\end{tabular}


Table 2 (continued)

\begin{tabular}{|c|c|c|c|c|c|c|c|c|c|c|c|}
\hline Model & AGE & & DEP & LNGDP & LNGDPSQ & CREDIT & CREDITSQ & CHGDP & RINT & R-squared & \# obs. \\
\hline \multicolumn{12}{|c|}{ Country fixed effects model with lags of LNGDP, LNGDPSQ, CREDIT, CREDITSQ, and CHGDP } \\
\hline \multirow[t]{3}{*}{7} & -1.34 & $* * *$ & -0.02 & $-24.63 * *$ & $1.96 * * *$ & 6.70 & -3.51 & & & 0.60 & 66 \\
\hline & 0.40 & & 0.20 & 8.40 & 0.47 & 6.22 & 2.13 & & & 0.59 & \\
\hline & -3.33 & & -0.09 & -2.93 & 4.17 & 1.08 & -1.65 & & & 0.66 & \\
\hline \multirow[t]{3}{*}{8} & -1.41 & $* * *$ & -0.02 & $-25.64 * *$ & $2.03 * * *$ & 6.75 & -3.32 & 0.19 & & 0.60 & 66 \\
\hline & 0.46 & & 0.20 & 8.86 & 0.52 & 6.45 & 2.24 & 0.15 & & 0.62 & \\
\hline & -3.10 & & -0.09 & -2.89 & 3.90 & 1.05 & -1.48 & 1.28 & & 0.68 & \\
\hline \multirow[t]{3}{*}{9} & -1.42 & $* *$ & 0.09 & -14.12 & 1.43 & 7.12 & -2.98 & $0.26 *$ & -0.07 & 0.55 & 62 \\
\hline & 0.51 & & 0.23 & 16.90 & 0.86 & 5.70 & 1.95 & 0.14 & 0.26 & 0.57 & \\
\hline & -2.77 & & 0.37 & -0.84 & 1.66 & 1.25 & -1.52 & 1.84 & -0.27 & 0.64 & \\
\hline \multicolumn{12}{|c|}{ Random effects model with lags of LNGDP, LNGDPSQ, CREDIT, CREDITSQ, and CHGDP } \\
\hline \multirow[t]{3}{*}{10} & -1.91 & $* * *$ & -0.14 & $-32.31 * * *$ & $2.39 * * *$ & 7.61 & -4.09 & & & 0.58 & 66 \\
\hline & 0.61 & & 0.13 & 10.43 & 0.73 & 7.40 & 2.52 & & & 0.70 & \\
\hline & -3.12 & & -1.08 & -3.10 & 3.29 & 1.03 & -1.62 & & & 0.73 & \\
\hline \multirow[t]{3}{*}{11} & -2.02 & $* * *$ & -0.14 & $-34.12 * * *$ & $2.51 * * *$ & 7.18 & -3.51 & $0.40 * *$ & & 0.58 & 66 \\
\hline & 0.68 & & 0.14 & 12.04 & 0.83 & 7.63 & 2.56 & 0.18 & & 0.74 & \\
\hline & -2.99 & & -0.98 & -2.83 & 3.03 & 0.94 & -1.37 & 2.17 & & 0.76 & \\
\hline \multirow[t]{3}{*}{12} & -1.93 & $* * *$ & -0.10 & -23.92 & $1.97 *$ & 5.02 & -2.70 & $0.37 * *$ & -0.17 & 0.52 & 62 \\
\hline & 0.72 & & 0.16 & 18.59 & 1.16 & 7.37 & 2.40 & 0.17 & 0.24 & 0.73 & \\
\hline & -2.68 & & -0.61 & -1.29 & 1.69 & 0.68 & -1.13 & 2.22 & -0.71 & 0.76 & \\
\hline
\end{tabular}

Notes: The figures are the estimated coefficients (first row), robust standard errors (second row), and t-values (third row). The first R-squared is within, the second is between, and the third is overall. The constant terms and country fixed effects are not shown to save space.

*Significant at the $10 \%$ level. **Significant at the $5 \%$ level. ***Significant at the $1 \%$ level. 
impact on domestic saving rates but their impact becomes more and more positive as income levels rise. Our results imply that, by 1976-80, income levels had become high enough for income levels to have a positive impact on domestic saving rates in nine out of the twelve economies in our sample, with income levels reaching this threshold by 1981-85 in India, by 1986-90 in China, and by 1991-95 in Viet Nam. Thus, by 1991-95, income levels had become high enough for income levels to have a positive impact on domestic saving rates in all twelve economies in our sample, as also found by Park and Shin (2009).

Turning to the financial variables, the availability of private credit exhibits a nonlinear (concave) relationship with the domestic saving rate, with the coefficient of CREDIT (the ratio of private credit to GDP) being positive and significant and the coefficient of its squared term being negative and significant in all cases. This nonlinear relationship indicates that financial sector development leads to a higher domestic saving rate up to a point, after which it works to lower the domestic saving rate, which is consistent with the theoretical model of Wang, $\mathrm{Xu}$, and $\mathrm{Xu}$ (2011) and with the discussions in Chinn and Prasad (2003) and Jha, et al. (2009). Our results imply that financial sector development has progressed enough in six of the twelve economies in our sample (PRC; Hong Kong, China; Korea; Malaysia; Singapore; and Taipei,China) for the availability of private credit to have a negative impact on the domestic saving rate in these economies but that financial sector development has not progressed enough in six of the twelve economies in our sample (India, Indonesia, Pakistan, Philippines, Thailand, and Viet Nam) for the availability of private credit to have a negative impact on the domestic saving rate.

Turning to the impact of CHGDP (the growth rate of real per capita GDP) and RINT (the 
real interest rate), the coefficient of CHGDP is positive, as expected, in all cases and significant in two out of four cases, and the coefficient of RINT is not stable in sign and is totally insignificant. This might be due to the often discussed fact that interest rates start to matter for saving behavior only after economic development has progressed beyond a certain threshold (see Ogaki, Ostry, and Reinhart, 1996).

Turning to the results for the models with lags (models $7-12$ ), the results are broadly consistent with the results for the models without lags: the coefficient of AGE is negative, as expected, and significant in all cases, the coefficient of DEP is negative, as expected, but totally insignificant in all cases, the coefficients of LNGDP and LNGDPSQ are negative and positive, respectively, and are significant in most (but not all cases), the coefficient of CHGDP is positive, as expected, and significant in three out of four cases, and the coefficient of RINT is negative but totally insignificant.

The biggest difference between the results for the models without lags and those for the models with lags is in the impact of financial sector development. The significant impact of financial sector development found in models 1-6 without lags disappears in models 7-12 with lags, which suggests the existence of simultaneity bias even though the signs of the relevant variables still indicate a concave impact of financial sector development on the domestic saving rate. Another difference is that the absolute magnitudes of the coefficients of AGE and CHGDP are larger in the case of the models with lags whereas the absolute magnitudes of the coefficients of LNGDP, LNGDPSQ, CREDIT, and CREDITSQ are larger in the case of the models without lags, which suggests that the models without lags exaggerate the impact of LNGDP, LNGDPSQ, CREDIT, and CREDITSQ due to 
simultaneity bias.

Finally, the results of the fixed effects models show that the country fixed effects are significant for most economies (except for Korea, Malaysia, and Singapore) with a significant negative sign when the PRC is taken as the reference country, indicating a much higher domestic saving rate in the PRC than predicted by the other explanatory variables.

As a robustness check, we also tried including time dummies for 7 out of the 8 time periods. When we did so, we found that the coefficients of 3 out of the 7 time dummies were significant at the 10 percent level (with the coefficients indicating a downward trend over time). However, a test for the joint significance of the time dummies failed to reject the null hypothesis that the coefficients of all of the time dummies are zero at the 5 percent significance level in the case of the benchmark model, and the results for the other explanatory variables were roughly comparable to those for the model without time dummies (except that the absolute magnitude of the coefficient of AGE becomes larger and the absolute magnitude of the coefficients of CREDIT and its squared term become smaller). Thus, we have not shown the results for the model that includes time dummies.

In sum, the main determinants of the domestic saving rate in developing Asia during the 1966-2007 period appear to be the age structure of the population (especially the aged dependency ratio), income levels, and (to a lesser extent) the level of financial sector development, except as noted above, and moreover, the direction of impact of each factor is more or less as expected. 


\section{Projections of Domestic Saving Rates in Developing Asia for 2011-2030}

In this section, we discuss our projections of domestic saving rates in the twelve developing Asian economies in our sample for 2011-2030. We should note at the start, however, that future projections over such a long time horizon are fraught with dangers and that we implicitly assume that there will be no changes in any factor (e.g., economic policies, institutions, etc.) other than those explicitly included in our analysis, which is not likely to be the case. Thus, our results should be taken with a grain of salt.

We show only the projections based on the fixed effects model because, while the results of standard specification tests such as the Hausman test and the Breusch and Pagan Lagrangian multiplier test suggest the use of random effects models, a test of the joint significance of the country fixed effects rejected the null hypothesis that the coefficients of all of the country fixed effects are zero, because the absolute magnitude of the coefficient of the aged dependency ratio seems unreasonably large in the estimation results based on the random effects model, as noted earlier, and because comparing out-of-sample projections based on the fixed effects and random effects models suggests that the random effects model does not perform as well as the fixed effects model in fitting the domestic saving rate for a number of economies such as the PRC, Korea, Singapore, Pakistan, and the Philippines. The projections from the random effects models underestimate the saving rates of the former three economies while overestimating those of the latter two economies. This is consistently true for all six random effects models. For the PRC, omitting the country fixed effect would yield a saving rate of about $24 \%$ of GDP for the 
2001-2007 period-10 percentage points lower than the actual rate. Our finding is remarkably consistent with Hung and Qian's (2010) finding that China's national saving rate is about 10 to 12 percentage points higher than that predicted by their regression analysis. A possible explanation for the case of the PRC is omitted factors such as the increase in the corporate saving rate during this period (IMF, 2009) and/or the distorted sex ratio of those of marrying age (Wei and Zhang, 2009). Another example of an obvious deviation of the fitted saving rate from the actual rate is the Philippines, where the fitted saving rate based on the random effects model does not show the decline observed in the actual rate. The rapidly increasing coverage of the social security system has been suggested as one of the explanations for why this might be (Terada-Hagiwara, 2009).

Our projections for the next two decades, 2011-2020 and 2021-2030, rely on the United Nations' (U.N.) projections of the age structure of the population (the aged and youth dependency ratios, median variant) and the GDP projections of Lee and Hong (2010).

Since projections of financial sector development are not available, we assumed that financial deepening progresses according to the level of per capita income. We projected in which World Bank income group each country would belong in 2011-2020 and 2021-2030 using Lee and Hong's (2010) GDP projections and assigned to each country the 2008 value of the financial sector development variable (private credit to GDP ratio) for the income group to which it is projected to belong in each time period except that, for economies in which the financial sector has already deepened beyond the average value for the income group to which they are projected to belong (Hong Kong, China; the PRC, Taipei,China, and Viet Nam in 2011-2020 and these same countries minus the PRC in 
2021-2030), the financial sector development variable was assumed to remain at the same value as in the recent past (the average value for 2000-2007). The average 2008 values of the financial sector development variable for each income group were $130 \%$ for the high income group, $105 \%$ for the upper middle income group, and $46 \%$ for the lower middle income group, as shown in Beck et al. (2008). Hong Kong, China; Korea; Malaysia; Singapore; the PRC; and Taipei,China are projected to belong to the high income group, Thailand to the upper middle income group, and Indonesia, India, Pakistan, the Philippines, and Viet Nam to the lower middle income group by 2021-2030.

Saving rate projections are generated for the 2011-2020 and 2021-2030 periods using the coefficients in model 7 of Table 2, the baseline country fixed effects model with lags, because simultaneity bias will presumably be less severe in the model with lags. Table 3 shows future projections of domestic saving rates for the twelve economies in our sample, and as can be seen from this table, domestic saving rates in Hong Kong, China; Indonesia; Korea; Malaysia; Philippines; Singapore; Thailand; and Taipei,China are expected to decrease (except for a slight upturn in Korea in 2021-30); that of Viet Nam is expected to increase in 2011-20, then decrease in 2021-30; that of the PRC is expected to remain roughly flat for the next two decades; and that of India and Pakistan are expected to increase (comparisons are being made to fitted values for the 2001-07 period).

While all of the developing Asian economies in our sample are projected to post steady growth, which will lead to higher income levels, which in turn will create upward pressure on their domestic saving rates, the dramatic differences among these economies in projected future trends in their domestic saving rates are not surprising because there is a 
40- to 50-year gap in the timing of population aging, as can be seen from Table 4 . As a result of these dramatic differences in the timing of the demographic transition in the coming decades, the decline in domestic saving rates will not occur simultaneously in the economies of developing Asia but will rather be spread out over close to a half-century, with the decline in domestic saving rates in some economies being offset by the increase in domestic saving rates in other economies until at least 2030.

In particular, economies in which population aging is expected to occur the soonest (such as Hong Kong, China; Korea; Singapore; Thailand; and Taipei,China) are projected to show the earliest declines in domestic saving rates, economies in which population aging

Table 3: Future Trends in Real Domestic Saving Rates in Developing Asia

\begin{tabular}{|l|r|r|r|}
\hline \multirow{2}{*}{ Economy } & \multicolumn{1}{c|}{$2001-07$} & \multicolumn{1}{c|}{ 2011-20 } & \multicolumn{1}{c|}{ 2021-30 } \\
\cline { 2 - 4 } & \multicolumn{1}{c|}{ Fitted } & Projected & Projected \\
\hline PRC & 31.82 & 30.30 & 31.88 \\
\hline Hong Kong, China & 29.75 & 24.33 & 20.02 \\
\hline Indonesia & 24.08 & 21.59 & 20.80 \\
\hline India & 14.54 & 14.92 & 15.91 \\
\hline Korea, Rep. of & 42.02 & 35.53 & 37.36 \\
\hline Malaysia & 44.65 & 43.74 & 41.97 \\
\hline Pakistan & 6.66 & 7.01 & 10.05 \\
\hline Philippines & 14.90 & 12.91 & 11.81 \\
\hline Singapore & 58.74 & 47.02 & 40.43 \\
\hline Thailand & 31.31 & 28.59 & 23.53 \\
\hline Taipei,China & 25.10 & 20.68 & 15.65 \\
\hline Viet Nam & 16.76 & 19.19 & 15.44 \\
\hline Developing Asia & 27.38 & 26.33 & 27.21 \\
\hline
\end{tabular}

Notes: Authors' calculation. Refer to the main text for explanation. 


\section{Table 4: Population Aging in Developing Asia}

\begin{tabular}{|l|c|}
\hline & $\begin{array}{c}\text { The Period during which the } \\
\text { Population Aged 65 and } \\
\text { Older Reaches 14 Percent } \\
\text { the Total Population }\end{array}$ \\
\hline Economy & $2020-25$ \\
\hline PRC & $2010-15$ \\
\hline Hong Kong, China & $2040-45$ \\
\hline Indonesia & $2050-55$ \\
\hline India & $2015-20$ \\
\hline Korea, Rep. of & $2040-45$ \\
\hline Malaysia & After 2055 \\
\hline Pakistan & $2050-55$ \\
\hline Philippines & $2015-20$ \\
\hline Singapore & $2020-25$ \\
\hline Thailand & $2015-20$ \\
\hline Taipei,China & $2030-35$ \\
\hline Viet Nam & $1990-95$ \\
\hline Japan & \\
\hline & \\
\hline $\begin{array}{l}\text { Data source: The United Nations' (U.N.) projections available } \\
\text { at http://esa.un.org/unpp, and the Statistical Yearbook for } \\
\text { Taipei, China, available at } \\
\text { http:/www.cepd.gov.tw/encontent/m1.aspx?sNo=0000063. }\end{array}$ \\
\hline
\end{tabular}

is expected to occur neither early nor late are projected to either show declines in domestic saving rates right from the start (as in the case of Indonesia, Malaysia, and the Philippines) or to show an increase in domestic saving rates early on, followed by a decline (as in the case of Viet Nam); and economies in which population aging is expected to occur the latest (such as India and Pakistan) are projected to show an increase in domestic saving rates at least until 2030. The primary exception is the PRC, where the domestic saving rate is projected to remain roughly constant for the next two decades (for the reason we will discuss shortly). 
The projected decline in domestic saving rates from the 2000s until the 2020s in the rapidly aging economies ranges from 5.4 percentage points (Korea) to 12.5 percentage points (Singapore), which is about the same or larger than what other already aging economies such as Japan have experienced over the last 20 years. In Japan, the domestic saving rate declined from its peak of $39 \%$ in the late 1980 s to $33 \%$ in the early 2000 s, during which time the aged dependency ratio rose from $16 \%$ to $29 \%$. The more pronounced decline in developing Asia's domestic saving rate might be due to the fact that aging is expected to progress more rapidly.

Finally, we calculate the historical and projected domestic saving rates of developing Asia as a whole by weighting the domestic saving rates for each economy by its real GDP (see Table 3). According to the fixed effects model, the domestic saving rate in developing Asia as a whole is projected to remain roughly constant for the next two decades-averaging $26.3 \%$ during the $2011-2020$ period and $27.2 \%$ during the $2021-2030$ period, compared to an actual value of $29.4 \%$ and a fitted value of $27.4 \%$ during the $2001-2007$ period.

The population of emerging Asia is projected to age rapidly over the next 20 years, with the aged dependency ratio expected to climb from 11 percent in 2001-2007 to 19 percent in 2021-2030. However, the domestic saving rate of developing Asia as a whole is expected to remain high despite the rapid aging of the population because of differences among economies in the timing of population aging and because the negative impact of population aging on the domestic saving rate will be largely offset by the positive impact of higher income (per capita GDP) levels on the domestic saving rate. ${ }^{1}$

1 Projections based on the random effects model indicate that the domestic saving rate in 
To corroborate this contention, we analyze the determinants of future trends in domestic saving rates with the help of Table 5, which shows the contribution of each factor to the change in the domestic saving rate of each country from the 2001-2007 period to the 2011-2010 period and from the 2011-2010 period to the 2021-2030 period. These contributions were calculated by multiplying the estimated coefficients of each factor from the country fixed effects model with lags (model 7 in Table 2) by the projected change in the factor in question during the period in question. Note, however, that in the case of (per capita) GDP and CREDIT, the contribution shown represents the sum of the contribution of the variable itself and that of the square of the variable.

As can be seen from this table, the change (increase) in AGE will lower the domestic saving rate in every country in both time periods, the change (decrease) in DEP will raise the domestic saving rate in 21 out of 24 cases, the change (increase) in GDP will increase the domestic saving rate in every country in both time periods, and the change (increase) in CREDIT will increase the domestic saving rate in 15 out of 24 cases. Note, however, that the contributions of DEP and CREDIT are not precisely estimated because they are calculated based on statistically insignificant coefficients and that their contributions are very small (in absolute magnitude) in any case.

developing Asia as a whole will decline from $29.2 \%$ in $2001-07$ to $26.6 \%$ in $2011-2020$ and further to $23.5 \%$ in $2021-2030$, contrary to the projections based on the country fixed effects model. However, as discussed earlier, the absolute magnitude of the coefficient of the aged dependency ratio seems unreasonably large in the estimation results based on the random effects model, and this is what is causing the domestic saving rate to show such a sharp decline. Thus, the projections based on the fixed effects model appear to be more credible than the results based on the random effects model. 
Table 5: The Contribution of Each Factor to Future Trends in Real Domestic Saving Rates in Developing Asia

\begin{tabular}{|l|l|r|r|r|r|r|}
\hline \multicolumn{1}{|c}{ Country } & Time Period & AGE & DEP & GDP & CREDIT & \multicolumn{1}{c}{ Total } \\
\hline PRC & $2011-2020$ & -5.83 & 0.11 & 4.31 & -0.12 & -1.52 \\
\hline PRC & $2021-2030$ & -8.80 & 0.02 & 10.36 & 0.00 & 1.58 \\
\hline Hong Kong, China & $2011-2020$ & -8.63 & 0.09 & 2.53 & 0.58 & -5.43 \\
\hline Hong Kong, China & $2021-2030$ & -9.61 & -0.05 & 5.36 & 0.00 & -4.30 \\
\hline Indonesia & $2011-2020$ & -2.69 & 0.17 & 0.91 & -0.89 & -2.49 \\
\hline Indonesia & $2021-2030$ & -5.26 & 0.10 & 3.26 & 1.11 & -0.79 \\
\hline India & $2011-2020$ & -2.02 & 0.23 & 1.66 & 0.51 & 0.38 \\
\hline India & $2021-2030$ & -3.59 & 0.13 & 3.99 & 0.46 & 0.98 \\
\hline Korea & $2011-2020$ & -9.76 & 0.15 & 2.94 & 0.18 & -6.49 \\
\hline Korea & $2021-2030$ & -4.40 & -0.01 & 6.38 & -0.14 & 1.84 \\
\hline Malaysia & $2011-2020$ & -3.96 & 0.20 & 2.32 & 0.53 & -0.91 \\
\hline Malaysia & $2021-2030$ & -6.08 & 0.11 & 4.49 & -0.30 & -1.77 \\
\hline Pakistan & $2011-2020$ & -0.92 & 0.23 & 0.97 & 0.06 & 0.35 \\
\hline Pakistan & $2021-2030$ & -1.63 & 0.16 & 3.58 & 0.92 & 3.04 \\
\hline Philippines & $2011-2020$ & -2.51 & 0.22 & 0.88 & -0.58 & -2.00 \\
\hline Philippines & $2021-2030$ & -3.58 & 0.12 & 1.86 & 0.51 & -1.09 \\
\hline Singapore & $2011-2020$ & -14.06 & 0.20 & 2.16 & -0.02 & -11.72 \\
\hline Singapore & $2021-2030$ & -10.70 & -0.06 & 4.33 & -0.16 & -6.59 \\
\hline Thailand & $2011-2020$ & -5.23 & 0.08 & 1.54 & 0.89 & -2.72 \\
\hline Thailand & $2021-2030$ & -9.59 & 0.02 & 4.53 & -0.02 & -5.06 \\
\hline Taipei,China & $2011-2020$ & -6.44 & 0.16 & 2.73 & -0.86 & -4.42 \\
\hline Taipei,China & $2021-2030$ & -9.16 & 0.01 & 4.13 & 0.00 & -5.02 \\
\hline Viet Nam & $2011-2020$ & -0.99 & 0.28 & 1.93 & 1.21 & 2.43 \\
\hline Viet Nam & $2021-2030$ & -8.04 & 0.04 & 4.25 & 0.00 & -3.74 \\
\hline & & & & & & \\
\hline
\end{tabular}

Note: Refer to the main text for variable definitions and a description of the calculation method.

The variables making by far the largest contributions (in absolute magnitude) to future trends in the domestic saving rate are AGE and GDP, with AGE making the largest contribution (in absolute magnitude) in 18 out of 24 cases and GDP making the largest contribution (in absolute magnitude) in 6 out of 24 cases. This corroborates my earlier contention that the downward pressure on the domestic saving rate caused by the increase in AGE will be largely offset by the upward pressure on the domestic saving rate caused by the increase in GDP. The impact of AGE will dominate in 10 economies in 2011-2020 and in 8 economies in 2021-2030, causing their domestic saving rates to decrease, on balance, whereas the impact of GDP will dominate in 2 economies in 2011-2020, in 4 economies in 
2021-2030, and in developing Asia as a whole, causing their domestic saving rates to increase, on balance.

Our results shed light on why the domestic saving rate of the PRC is projected to remain more or less unchanged during the next two decades. The reason is that the substantial downward pressure thereon caused by the rapid aging of her population will be roughly offset by the substantial upward pressure thereon caused by higher income (per capita GDP) levels.

The trajectory of the domestic saving rate in developing Asia as a whole appears to be heavily influenced by trends in the PRC, which will account for more than $50 \%$ of regional GDP in the next two decades. Thus, any developments in the PRC that affect its domestic saving rate (such as the worsening of its fiscal balance, increases in expenditures on social services and pensions, and/or changes in the speed of population aging) have important ramifications for future trends in saving rates in developing Asia as a whole.

\section{Summary and Conclusions}

In this paper, we presented data on trends over time in domestic saving rates in twelve economies in developing Asia during the 1966-2007 period, conducted an econometric analysis of the determinants of those trends, and projected trends in domestic saving rates in these same economies during the next twenty years (2011-2030 period) based on our estimation results. We found that domestic saving rates in developing Asia have, in general, been high and rising but that there have been substantial differences from 
economy to economy, that the main determinants of the domestic saving rate in developing Asia during the 1960-2007 period appear to have been the age structure of the population (especially the aged dependency ratio), income levels, and the level of financial sector development, and moreover, that the direction of impact of each factor has been more or less as expected. We also found that the domestic saving rate in developing Asia as a whole will remain roughly constant during the next two decades because the negative impact of population aging thereon will be roughly offset by the positive impact of higher income levels thereon but that there will be substantial variation from economy to economy, with the rapidly aging economies showing a sharp downturn in their domestic saving rates by 2030, because the negative impact of population aging thereon will dominate the positive impact of higher income levels thereon, and the less rapidly aging economies showing rising domestic saving rates, at least until 2020, because the positive impact of higher income levels thereon will dominate the negative impact of population aging thereon. 


\section{References}

Aghion, Philippe; Comin, Diego; Howitt, Peter; and Tecu, Isabel (2009), "When Does Domestic Saving Matter for Economic Growth?” mimeo. (Harvard University).

Apergis, Nicholas, and Tsoumas, Chris (2009), "A Survey of the Feldstein-Horioka Puzzle: What Has Been Done and Where We Stand," Research in Economics, vol. 63, no. 2 (June), pp. 64-76.

Asian Development Bank (2009), "Rebalancing Asia's Growth,” in Asian Development Bank ed., Asian Development Outlook 2009 (Manila, Asian Development Bank).

Bailliu, J., and Reisen, H. (1998), "Do Funded Pensions Contribute to Higher Savings? A Cross-Country Analysis,” OECD Development Centre manuscript, Paris.

Beck, Thortsen and Demirgüç-Kunt, Asli (2009), "Financial Institutions and Markets Across Countries and over Time: Data and Analysis," World Bank Policy Research Working Paper No. 4943 (May), The World Bank, Washington, D.C.

Bernanke, Ben (2005), "The Global Saving Glut and the U.S. Current Account Deficit," Remarks made at the Sandridge Lecture, Virginia Association of Economics, Richmond, Virginia. Available at http://www.federalreserve.gov/boarddocs/speeches/2005/200503102/.

Bosworth, Barry, and Chodorow-Reich, Gabriel (2007), "Saving and Demographic Change: The Global Dimension," CRR WP 2007-02, Center for Retirement Research, Boston College, Boston, MA

CEIC data manager, WEB. New York, N.Y.

Chinn, Menzie D., and Ito, Hiro (2007), "Current Account Imbalances, Financial Development and Institutions: Assaying the World 'Saving Glut,' " Journal of International Money and Finance, vol. 26, no. 4 (June), pp. 546-569.

Chinn, Menzie D., and Ito, Hiro (2008), "Global Current Account Imbalances: American Fiscal Policy versus East Asian Savings," Review of International Economies, vol. 16, no. 3 (August), pp. 479-498. 
Chinn, Menzie D., and Prasad, Eswar S. (2003), "Medium-term Determinants of Current Account in Industrial and Developing Countries: An Empirical Exploration," Journal of International Economics, vol. 59, no. 1, pp. 47-76.

Dayal-Ghulati, A., and Thimann, C. (1997), "Saving in Southeast Asia and Latin America Compared: Searching for Policy Lessons," IMF Working Paper WP/97/110, International Monetary Fund, Washington, D.C.

Edwards, Sebastian (1996), "Why Are Latin America's Savings Rates So Low? An International Comparative Analysis," Journal of Development Economics, vol. 51, no. 1, pp. 5-44.

Feldstein, Martin (1977). "Social Security and Private Savings: International Evidence in an Extended Life Cycle Model," in Martin Feldstein and Robert Inman, eds., The Economics of Public Services (An International Economic Association Conference Volume).

Feldstein, Martin (1980), "International Differences in Social Security and Saving," Journal of Public Economics, vol. 14, no. 2 (October), pp 225-244.

Feldstein, Martin S., and Horioka, Charles Y. (1980), "Domestic Saving and International Capital Flows," Economic Journal, vol. 90, no. 358 (June), pp. 314-329.

Heston, Alan; Summers, Robert; and Aten, Bettina (2009), Penn World Table Version 6.3, Center for International Comparisons of Production, Income and Prices at the University of Pennsylvania, August 2009.

Higgins, M. (1998), "Demography, National Savings, and International Capital Flows," International Economic Review, vol. 39, no. 2 (May), pp. 343-369.

Horioka, Charles Yuji (1989), “Why Is Japan's Private Saving Rate So High?” in Ryuzo Sato and Takashi Negishi, eds., Developments in Japanese Economics (Tokyo: Academic Press/Harcourt Brace Jovanovich, Publishers), pp. 145-178.

Horioka, Charles Yuji (1992), "Future Trends in Japan's Saving Rate and the Implications Thereof for Japan's External Imbalance," Japan and the World Economy, vol. 3, no. 4 
(April), pp. 307-330.

Horioka, Charles Yuji, and Terada-Hagiwara, Akiko (2011), "Relationship between Saving and Investment in Developing Asia," mimeo., Asian Development Bank, Manila, The Philippines.

Horioka, Charles Yuji, and Yin, Ting (2010), "Household Saving Rates and Social Benefit Ratios: Country Comparisons," in Masahiro Kawai and Gloria O. Pasadilla, eds., Effects of Social Policy on Domestic Demand: Annual Conference 2009 (Tokyo, Japan: Asian Development Bank Institute (ADBI)), pp. 63-75.

Hung, Juann H. and Qian, Rong (2010), "Why Is China's Saving Rate So High? A Comparative Study of Cross-Country Panel Data,“ Working Paper Series 2010-07, Congressional Budget Office, Washington, D.C.

International Monetary Fund (2005), "Global Imbalances: A Saving and Investment Perspective," in International Monetary Fund, ed., World Economic Outlook 2005 (Washington, D.C.: International Monetary Fund).

International Monetary Fund (2009), "Corporate Savings and Rebalancing in Asia" in International Monetary Fund, ed., World Economic and Financial Surveys, Regional Economic Outlook, Asia and Pacific 2009 (Washington, D.C.: International Monetary Fund).

International Monetary Fund. International Financial Statistics. Washington, DC: International Monetary Fund. Various issues.

Ito, Hiro, and Chinn, Menzie (2009), "East Asia and Global Imbalances: Saving, Investment, and Financial Development," in Takatoshi Ito and Andrew K. Rose, eds., Financial Sector Development in the Pacific Rim (East Asian Seminar on Economics, National Bureau of Economic Research conference volume, vol. 18 (Chicago: University of Chicago Press), pp. 117-150.

James, William E.; Naya, Seiji; and Meier, Gerald M. (1989), "Domestic Savings and Financial Development," in Asian Development, Economic Success and Policy Lessons (Madison, Wisconsin: The University of Wisconsin Press, Ltd.). 
Jha, Shikha; Prasad, Eswar; and Terada-Hagiwara, Akiko (2009), "Saving in Asia: Issues for Rebalancing Growth,” ADB Economics Working Paper Series no. 162, Asian Development Bank, Manila, Philippines.

Kim, Soyoung, and Lee, Jong-Wha (2008), "Demographic Changes, Saving, and Current Account: An Analysis based on a Panel VAR Model," Japan and the World Economy, vol. 20, no. 2 (March), pp. 236-256.

King, Robert and Levine, Ross (1993), "Finance, Entrepreneurship and Growth: Theory and Evidence," Journal of Monetary Economics, vol. 32, issue 3 (December), pp 513-542.

Lee, Jong-Wha, and Hong, Kiseok (2010), "Economic Growth in Asia: Determinants and Prospects," forthcoming in ADB Economics Working Paper Series no. 220, Asian Development Bank, Manila, Philippines (September).

Loayza, Norman; Schmidt-Hebbel, Klaus; and Serven, Luis (2000), "What Drives Private Saving across the World?" Review of Economics and Statistics, vol. 82, no. 2 (May), pp. 165-181.

Luhrman, M (2003), "Demographic Change, Foresight and International Capital Flows," MEA Discussion Paper Series 03038, Mannheim Institute of the Economics of Aging, University of Mannheim, Germany.

Modigliani, Franco (1970), "The Life-cycle Hypothesis and Intercountry Differences in the Saving Ratio," in W. A. Eltis, M. FG. Scott, and J. N. Wolfe, eds., Induction, Growth, and Trade: Essays in Honour of Sir Roy Harrod (Oxford: Oxford University Press). pp. $197-225$.

Modigliani, Franco, and Sterling, Arlie (1983), "Determinants of Private Saving with Special Reference to the Role of Social Security: Cross Country Tests," in Franco Modigliani and Richard Hemming, eds., The Determinants of National Saving and Wealth (Proceedings of a Conference held by the International Economic Association at Bergamo, Italy) (London: Macmillan).

Ogaki, Masao ; Ostry, Jonathan D.; and Reinhart, Carmen M. (1996), "Saving Behavior in Low- and Middle-Income Developing Countries: A Comparison," International Monetary Fund Staff Papers, vol. 43, no. 1 (March), pp. 38-71 
Park, Donghyun, and Shin, Kwanho (2009), "Saving, Investment, and Current Account Surplus in Developing Asia," ADB Economics Working Paper Series no. 158, Asian Development Bank, Manila, Philippines (April).

Shioji, Etsuro, and Vu, Tuan Khai (2011), "Physical Capital Accumulation in Asia-12: Past Trends and Future Projections," ADB Economics Working Paper series no. 240, Asian Development Bank, Manila, Philippines.

Terada-Hagiwara, Akiko (2009), "Explaining Filipino Households' Declining Saving Rate," ADB Economics Working Paper Series no. 178, Asian Development Bank, Manila, Philippines (November).

Wang, Pengfei; Xu, Lifang; and Xu, Zhiwei (2011), "Financial Development and Aggregate Saving Rates: A Hump-Shaped Relationship," mimeo., Hong Kong University of Science and Technology, Hong Kong (October).

Wei, Shang-Jin, and Zhang, Xiaobo (2009), "The Competitive Saving Motive: Evidence from Rising Sex Ratios and Savings Rates in China," NBER Working Paper No. 15093 (September), National Bureau of Economic Research, Inc., Cambridge, Massachusetts.

World Bank. World Development Indicators. Washington, D.C.: World Bank. Various issues. 


\section{Appendix Table 1: Variable Definitions and Data Sources}

\begin{tabular}{|c|c|c|c|}
\hline Variable & Var. name & Data source & Notes \\
\hline $\begin{array}{l}\text { Real domestic } \\
\text { saving rate }\end{array}$ & SR & $\begin{array}{l}\text { Computed as } 100-\mathrm{kg}-\mathrm{kc} . \\
\text { Heston, et al. (2009), Penn } \\
\text { World Table (PWT), version } 6.3 \\
\text { 1/ }\end{array}$ & $\begin{array}{l}\mathrm{kg} \text { is the government share of } \\
\text { real per capita GDP, and kc } \\
\text { is the consumption share of } \\
\text { real per capita GDP. Both } \\
\text { from PWT. }\end{array}$ \\
\hline $\begin{array}{l}\text { Aged dependency } \\
\text { ratio }\end{array}$ & AGE & $\begin{array}{l}\text { "SP.POP.DPND.OL" from } \\
\text { World Development Indicators } \\
\text { (WDI) of the World Bank } 2 / \text { and } \\
\text { the Statistical Yearbook for } \\
\text { Taipei,China 3/ }\end{array}$ & $\begin{array}{l}\text { Ratio of the population aged } \\
65 \text { or older to the population } \\
\text { aged } 15-64\end{array}$ \\
\hline $\begin{array}{l}\text { Youth dependency } \\
\text { ratio }\end{array}$ & DEP & $\begin{array}{l}\text { "SP.POP.DPND.YG" from WDI } \\
\text { and the Statistical Yearbook for } \\
\text { Taipei,China }\end{array}$ & $\begin{array}{l}\text { Ratio of the population aged } \\
0-14 \text { to the population aged } \\
15-64\end{array}$ \\
\hline $\begin{array}{l}\text { Real per capita } \\
\text { GDP }\end{array}$ & LNGDP & $\begin{array}{l}\text { "rgdpch" from Penn World } \\
\text { Table, version } 6.3\end{array}$ & $\begin{array}{l}\text { Real per capita GDP ( } 2005 \\
\text { constant prices: Laspeyres) }\end{array}$ \\
\hline $\begin{array}{l}\text { Real per capita } \\
\text { GDP growth rate }\end{array}$ & CHGDP & $\begin{array}{l}\text { "grgdpch" from Penn World } \\
\text { Table, version } 6.3\end{array}$ & $\begin{array}{l}\text { Growth rate of real per capita } \\
\text { GDP (chain series) (rgdpch) }\end{array}$ \\
\hline $\begin{array}{l}\text { Private credit from } \\
\text { deposit money } \\
\text { banks and other } \\
\text { financial } \\
\text { institutions (\% of } \\
\text { GDP) }\end{array}$ & CREDIT & $\begin{array}{l}\text { "pcrdbofgdp" from Beck and } \\
\text { Demirguc-Kunt (2009) and line } \\
32 \text { D from International } \\
\text { Financial Statistics (IFS) of the } \\
\text { International Monetary Fund } \\
\text { for the PRC }\end{array}$ & \\
\hline $\begin{array}{l}\text { Nominal interest } \\
\text { rate }\end{array}$ & INT & $\begin{array}{l}\text { IFS, and www.cbc.gov.tw } \\
\text { (Taipei,China's central bank's } \\
\text { website) for Taipei,China. 8/ }\end{array}$ & $\begin{array}{l}\text { Used data on the deposit rate } \\
\text { (line } 60 \mathrm{~L} \text { of IFS) except for } \\
\text { India, Pakistan, and the } \\
\text { Republic of Korea, for which } \\
\text { we used the discount rate } \\
\text { (line } 60 \text { of IFS) }\end{array}$ \\
\hline Inflation rate & INFL & $\begin{array}{l}\text { “NY.GDP.DEFL.KD.ZG” from } \\
\text { WDI }\end{array}$ & $\begin{array}{l}\text { Used the rate of change of the } \\
\text { GDP deflator }\end{array}$ \\
\hline Real interest rate & RINT & IFS, WDI, and www.cbc.gov.tw & $\begin{array}{l}\text { Computed as } \ln ((1+\mathrm{INT} / 100) / \\
(1+\mathrm{INFL} / 100))\end{array}$ \\
\hline
\end{tabular}


Appendix Table 1 (continued)

Notes:

1/ Available at http://pwt.econ.upenn.edu/php_site/pwt_index.php

2/ Available at http://devdata.worldbank.org/dataonline/

3/ Available at http://www.cepd.gov.tw/encontent/m1.aspx?sNo=0000063

4/ Available at http://www.dbm.gov.ph/index.php?id=32\&pid=9

5/ Available at http://www.adb.org/Statistics/ki.asp

6/ Available at http://www.bot.or.th

7/ Available at http://www.bnm.gov.my

8/ Available at http://www.cbc.gov.tw/ct.asp?xItem $=30010 \& \mathrm{CtNode}=517 \& \mathrm{mp}=2$ 
Appendix Table 2: Descriptive Statistics

\begin{tabular}{|l|r|r|r|r|r|}
\hline Variable & No. of Obs. & Mean & Std. Dev. & Minimum & Maximum \\
\hline SR & 78 & 25.2 & 14 & -3.8 & 60.2 \\
\hline AGE & 78 & 7.8 & 2.2 & 5.7 & 16.3 \\
\hline DEP & 78 & 56.8 & 18.6 & 20.3 & 87.6 \\
\hline LNGDP & 78 & 8.5 & 0.9 & 6.7 & 10.5 \\
\hline CREDIT & 78 & 0.7 & 0.5 & 0.1 & 2.2 \\
\hline CHGDP & 78 & 4.6 & 2.8 & -2.7 & 12.3 \\
\hline RINT & 70 & 1.1 & 3 & -7.5 & 8.7 \\
\hline
\end{tabular}

Note: Refer to Appendix Table 1 for variable definitions and data sources. 